\title{
Lombo preto
}

Joyce Maria dos Reis Santana ${ }^{1}$

Em meu âmago amargo ouço um eco agitado

Preto

Preto encarnado

O rufar de tambores

O repique quebrado do berimbau

Pretos pés encharcados de um vermelho enjaulado muito tempo atrás

Ouço o eco açoitado

Existir

Resistir

Existi

Resisti

É que dói

Em quem dói?

Essa vontade negra em ser branca

Pele rósea

Clitóris de marfim

Essa vontade branca em ser negra encarnada

Tronco ereto

Pixaim!

E o repuxo no lombo

quem aguenta?

Quem não tenta desistir?

Quem não tenta

${ }^{1}$ Doutoranda em Literatura e Cultura. 
Existir?

É que dói

Em quem dói?

$A i$, ai meu pixaim!

Meu lombo preto não vai

vai

não vai permanecer assim

Pintei meu quarto de preto

Preto?

Preto Preto Pretim

Pra quando chegar da rua branca

branca? Qual branca!

branca branca branca, Sim!

Pintei meu quarto de preto

pra pisar meu pé vermelho de sangue negro no chão

sem deixar rastro do sangue

De minha Mãe

África em mim

Pintei meu quarto de preto

A cara

A boceta

O falo

A língua

O caralho

Cu e jardim do vizim

Pintei meu quarto de Preto

Pra me respeitar

Olhar na cara retinta

\section{8}


Preta e bonita

Bonita e preta, sim

Pintei meu quarto de preto

E pinto a genocida herança que guerreia (e me faz guerrear) com o preto em mim.

Recebido em 04/02/2019

Aceito em 13/05/2019 